\title{
ANALISIS PENGENDALIAN KUALITAS PRODUK UNTUK MEMINIMUMKAN PRODUK GAGAL PADA PABRIK ROTI PRABU BAKERY
}

\author{
Nia Friscilla ${ }^{1}$, Achmad Syamsudin ${ }^{2 *}$, Deddy Rakhmad Hidayat ${ }^{3 *}$ \\ 1,2,3 Fakultas Ekonomi dan Bisnis, Universitas Palangka Raya \\ Corresponding: Syams achmad@feb.upr.ac.id, deddyrakhmadhidayat@feb.upr.ac.id
}

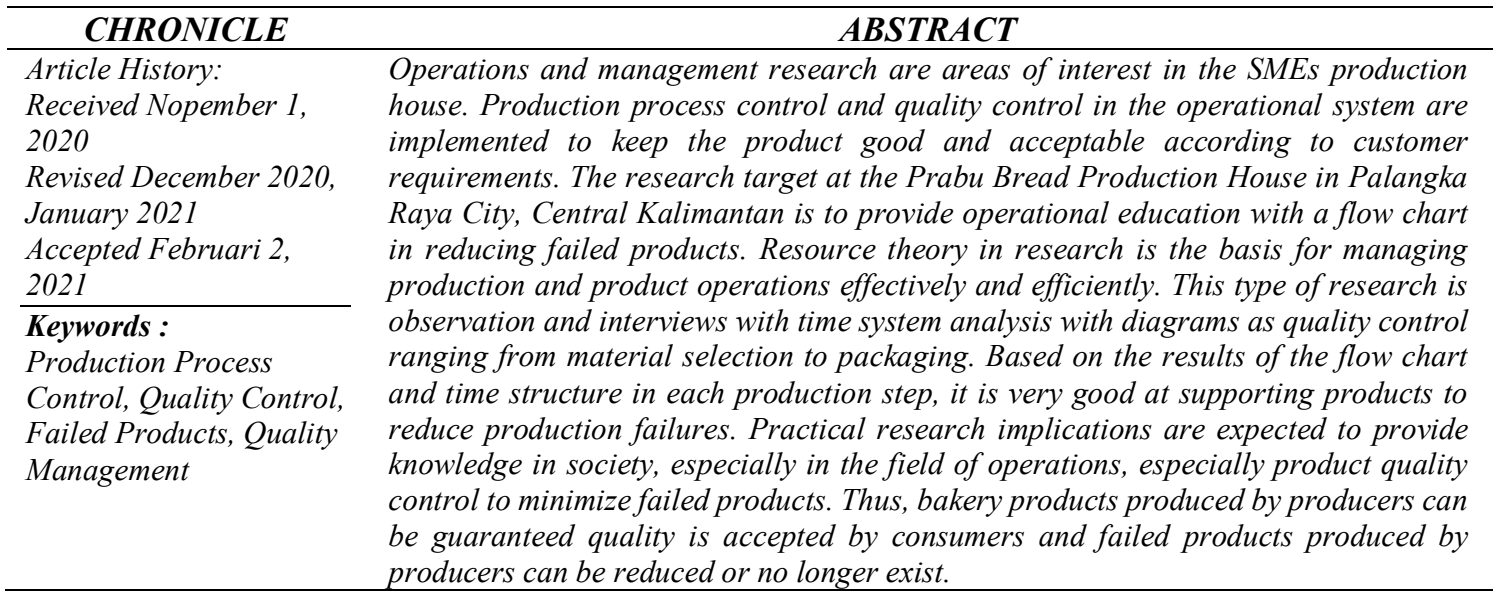

\section{Latar Belakang}

Suatu perusahaan, baik perusahaan jasa maupun perusahaan manufaktur tidak akan lepas dari konsumen dan produk yang dihasilkannya. Konsumen adalah hal yang sangat berperan dalam kemajuan suatu usaha, yang mana disini konsumen sebagai mitra bisnis untuk pembelian produk dari perusahaan. Konsumen tentunya berharap bahwa produk yang ditawarkan perusahaan tersebut memiliki kondisi yang baik serta terjamin [1]. Oleh sebab itu perusahaan harus menjaga kualitas produknya sehingga produk yang dihasilkan baik dan terjamin sampai diterima oleh tangan konsumen serta mampu bersaing di pasar [2].

Apabila pengendalian kualitas dilakukan dengan baik, bagi perusahaan hal ini akan menimbulkan tambahan biaya pengawasan kualitas dan tingkat kegagalan produk yang dihasilkan akan sedikit [3]. Sebaliknya, jika perusahaan perusahaan tidak memperhatikan pengendalian kualitas, maka dalam jangka pendek perusahaan tidak perlu mengeluarkan biaya pengawasan kualitas, akan tetapi dalam jangka panjang perusahan sulit memasarkan produk, dikarenakan tersaingi dengan perusahaan yang sejenis dengan kualitas produk yang lebih baik serta jumlah produk gagal semakin banyak, hal ini dapat menyebabkan kerugian bagi perusahaan.

Salah satu tindakan yang dapat dilakukan untuk mengetahui apakah produk yang rusak berada dalam batas toleransi yang telah ditetapkan oleh perusahaan adalah menggunakan alat bantu statistik yaitu Statistical Quality Control [4]. Ditetapkannya suatu sistem pengendalian kualitas diharapkan dapat meminimalisir terjadinya kerusakan produk (product defect) sampai pada tingkat kerusakan nol (zero defect), sehingga perlu dilakukan analisa mengenai upaya pengendalian kualitas yang diterapkan oleh Prabu Bakery dan mencari solusi perbaikan dengan menggunakan alat bantu statistik sehingga presentase produk gagal dapat ditekan menjadi seminimum mungkin [5]. Hal ini menunjukkan bahwa jumlah produksi yang dilakukan Prabu Bakery tidaklah sama, menurut Prabu Bakery ini dikarenakan roti yang dititipkan ke tokotoko masih cukup banyak sehingga roti tersebut dibawa kembali oleh Prabu Bakery maka dari itu produksi dikurangi pada esok harinya. Jumlah produk gagal yang dilakukan di Prabu Bakery ini setiap bulannya pun tidak sama, hal ini tergantung pada jumlah produksi roti tersebut. Dapat dilihat bahwa kerusakan yang terjadi pada produksi roti Prabu Bakery masih cukup tinggi yakni rata-rata kerusakan sebanyak 1,11\% dari jumlah produksi. Kegagalan tersebut seperti roti yang gosong, tekstur roti padat di dalam dan ukuran yang tidak sesuai menyebabkan adanya produk yang gagal dan tidak sesuai dengan standar kualitas yang diharapkan.

Masih terdapatnya kegagalan dalam produksi roti, artinya Prabu Bakery belum secara optimal menerapkan pengendalikan pengendalian kualitas produksi. Untuk itu Prabu Bakery harus melakukan penerapan pengendalian kualitas dalam mengatasi hal tersebut, guna memperbaiki dan mencari tingkat kerusakan yang paling dominan dengan menggunakan alat bantu statistik sehingga persentase produk yang gagal/rusak dapar ditekan seminimum mungkin bahkan mencapai zero defect (cacat nol). Sehingga 
penelitian ini memiliki tujuan untuk menjaga kualitas produk/ pengendalian dalam mengurangi produk gagal produksi roti.

\section{Tinjauan Pustaka}

Kualitas yang digunakan oleh American Society for Quality (ASQ) adalah "keseluruhan fitur dan karakteristik sebuah produk atau jasa yang mengandalkan pada kemampuannya untuk memuaskan kebutuhan yang dijanjikan dan tersirat". Kualitas bisa diartikan sebagai produk yang bebas cacat. Dengan kata lain, produk sesuai dengan standar (target sasaran atau persyaratan yang bisa disefinisikan, diobservasi dan diukur [6-9].

Terdapat tiga ukuran kualitas yang dapat digunakan untuk barang sebagai berikut:

a. Kualitas Desain

Kualitas desain barang sangat berhubungan dengan sifat-sifat keunggulan pada saat barang mula-mula diimpikan. Hal ini merupakan refleksi dari riset pasar yang intensif untuk memastikan kebutuhan pasar dan kemudian menyesuaikannya. Misalnya, oven microwave merupakan produk yang menggunakan teknologi baru untuk memasak lebih cepat, hemat energi jika dibandingkan dengan oven konvensional. Kualitas desain dipengaruhi oleh beberapa faktor, yaitu: kualitas input, teknologi yang digunakan, kualitas tenaga kerja dan manajer.

b. Kualitas Penampilan

Aspek ini mencakup performa produk dimasa yang akan datang, yang dipengaruhi oleh dua faktor, yaitu: Pertama, keadaan produk yang berhubungan dengan waktu penggunaan sebelum terjadi kerusakan. Kedua, perawatan produk yang berhubungan dengan kemampuan mereparasi dan mengganti dengan cepat produk yang rusak.

c. Kualitas yang memenuhi

Berhubungan dengan apakah produk yang dihasilkan memenuhi spesifikasi yang telah ditetapkan atau yang diharapkan, dengan kata lain sejauh mana kualitas suatu produk dapat dicapai. Dalam hal ini terdapat tiga faktor yang mempengaruhi conformance quality, yaitu usia teknik produk, pengaruh produk dan ketepatan produk.

\subsection{Faktor-Faktor yang Mempengaruhi Kualitas}

Secara khusus faktor-faktor yang mempengaruhi kualitas [7,9], yaitu:

a. Pasar atau Tingkat Persaingan, ialah semakin tinggi tingkat persaingan akan memberikan pengaruh pada perusahaan untuk menghasilkan produk yang berkualita.

b. Tujuan Organisasi, Apakah perusahann bertujuan menghasilkan volume output tinggi, barang yang berharga rendah, atau menghasilkan barang yang berharga mahal.

c. Testing Produk, merupakan testing yang kurang memadai terhadap produk yang dihasilkan dapat berakibat kegagalan dalam mengungkapkan kekurangan yang terdapat pada produk.

d. Proses Produksi, merupakan prosedur untuk memproduksi produk dapat juga menentukan kualitas produk yang dihasilkan

e. Desain Produksi, merupakan cara mendesain produk pada awalnya dapat menentukan kualitas produk itu sendiri.

f. Kualitas Input, merupakan jika bahan yang digunakan tidak memenuhi standar, tenaga kerja tidak terlatih, atau perlengkapan yang digunakan tidak tepat, maka akan berakibat pada produk yang dihasilkan

g. Perawatan Perlengkapan, jika perlengkapan tidak dirawat secara tepat atau suku cadang tidak tersedia, maka kualitas produk akan kurang dari semestinya

h. Standar Kualitas, merupakan perhatian terhadap kualitas dalam organisasi tidak tampak, tidak ada testing maupun inspeksi, maka output yang berkualitas tinggi sulit dicapai.

i. Umpan Balik Konsumen, merupakan apabila perusahaan kurang sensitif terhadap keluhan konsumen, kualitas tidak akan meningkat secara signifikan.

\subsection{Pengendalian Kualitas}

Pengertian pengendalian mutu/kualitas (Quality Control) adalah proses untuk memastikan bahwa barang dan jasa yang diproduksi sesuai dengan spesifikasi desain produk [10]. Selanjutnya pengendalian kulitas adalah penggabungan teknik serta aktivitas operasional yang bertujuan untuk memenuhi syarat standar sebuah kualitas. Definisi pengendalian adalah keseluruhan fungsi kegiatan yang harus dilakukan 
untuk menjamin tercapainya sasaran perusahaan dalam hal kulitas produksi dan jasa pelayanan yang diproduksi [11]. Dari pendapat para ahli di atas, dapat disimpulkan bahwa pengendalian kualitas ialah proses atau kegiatan untuk memastikan bahwa barang dan jasa sesuai dengan spesifikasi desain produk serta memenuhi syarat standar kualitas untuk tercapainya sasaran perusahaan.

\subsection{Pengendalian Mutu Bahan Baku}

Bahan baku dengan mutu yang baik akan menghasilkan produk baik dan sebaliknya jika mutu bahan baku buruk akan menghasilkan produk buruk. Pengendalian mutu bahan baku harus dilakukan sejak penerimaan bahan baku di gudang, selama penyimpanan dan waktu bahan baku akan dimasukkan dalam proses produksi.

\section{Pengendalian Proses Produksi}

Bahan baku yang telah diterima gudang, selanjutnya diproses untuk diolah menjadi barang jadi. Selain cara kerja peralatan produksi yang mengolah bahan baku dipantau, hasil kerja mesin-mesin juga dipantau agar menghasilkan produk yang diharapkan. Pengendalian mutu selama proses produksi dilakukan dengan cara mengambil sampel pada selang waktu yang sama. Sampel tersebut dianalisis, bila tidak sesuai berarti proses produksinya terdapat kesalahan dan harus diperbaiki.

\section{Pengendalian Mutu Produk Jadi}

Pemeriksaan terhadap produk jadi dilakukan untuk mengetahui apakah produk sesuai dengan mutu yang diharapkan atau tidak. Bila produk sesuai dengan standar yang telah ditetapkan oleh perusahaan maka produk tersebut dapat dipasarkan atau didistribusikan. Bila terdapat produk yang cacat, maka produk tersebut harus dibuang dan perlu dilakukan identifikasi penyebab terjadinya kegagalan produk tersebut.

3. Pengendalian pengepakan atau kemasan

Kemasan merupakan alat untuk melindungi produk agar tetap dalam kondisi sesuai dengan mutu. Tetapi ada pula produk yang tidak begitu memerlukan perhatian khusus dalam hal kemasan, misalnya sayuran, kelapa, dan sebagainya. Akan tetapi, tetap harus memilih alat angkut yang tepat agar produk sampai tujuan dengan mutu tetap prima.

\subsection{Statistical Quality Control (SQC)}

Statistical Quality Control merupakan metode statistik untuk mengumpulkan dan menganalisa data hasil pemeriksaan terhadap sampel dalam kegiatan pengawasan kualitas produk. SQC dilakukan dengan pengambilan sampel (sampling) dari "populasi" dan menarik kesimpulan berdasar karakteristikkarakteristik sampel tersebut secara statistik (statistical inference). Pengendalian kualitas secara statistik dengan menggunakan metode SQC (Statistical Quality Control) mempunyai 7 (tujuh) alat statistik utama yang dapat digunakan sebagai alat bantu untuk mengendalikan kualitas, check sheet, histogram, control chart, diagram pareto, diagram sebab akibat, scatter diagram, dan diagram proses. Berikut adalah contoh diagram alir dapat dilihat pada Gambar 2.1:

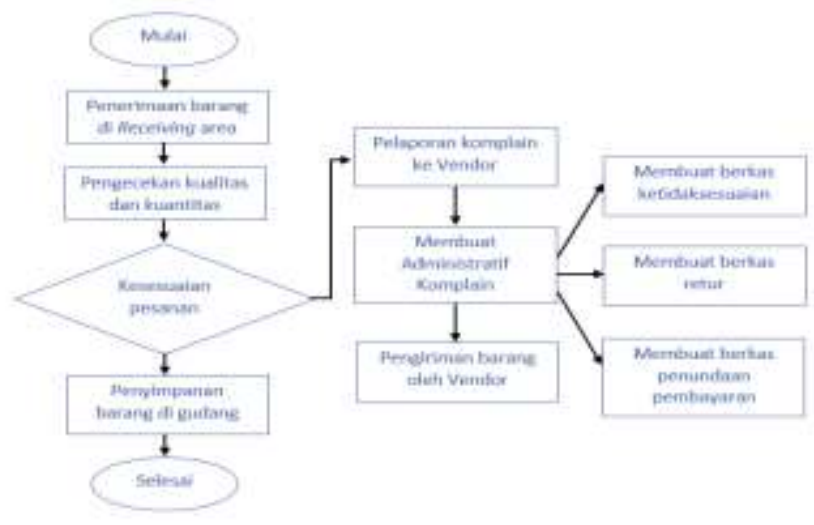

Gambar 2.1 Proses pengendalian kualitas (SQC), dibuat penulis,2020

Diagram alir secara grafis menunjukkan sebuah proses atau sistem dengan menggunakan kotak dan garis yang saling berhubungan [12-14]. A) diagram alir ini cukup sederhana, tetapi merupakan alat yang sangat baik untuk mencoba memahami sebuah proses atau menjelaskan langkah-langkah sebuah proses. Selanjutnya, B) lembar pengecekan adalah suatu formulir yang didesain untuk mencatat data. 
Lembar pengecekan membantu analisis menentukan fakta yang mungkin dapat membantu analisis selanjutnya. Misalnya gambar yang menunjukkan suatu perhitungan jumlah daerah dimana cacat terjadi, atau sebuah lembar pengecekan yang menunjukkan tipe keluhan pelanggan. C). Histogram menunjukkan peristiwa yang paling sering terjadi dan juga variasi dalam pengukuran. Histogram mempermudah dalam membaca atau menjelaskan data dengan cepat. Histogram adalah alat penyajian data secara visual berbentuk grafik balok yang memperlihatkan distribusi nilai yang diperoleh dalam bentuk angka.

\section{Metode Penelitian}

Penelitian adalah jenis observasi dan wawancara, sehingga untuk mempermudah dalam interprestasi hasil maka dibangunlah diagram alir untuk langkah dalam penuangan hasil [15-17]. Terkait dengan sifat penelitan ini yaitu menggambarkan secara deskriptif, maka dalam melakukan pengolahan data yang diperoleh peneliti menggunakan metode Statistical Quality Control (SQC). Terdapat 7 (tujuh) alat Statistical Quality Control. Adapun langkah-langkah analisa data dalam penelitian ini adalah sebagai berikut.

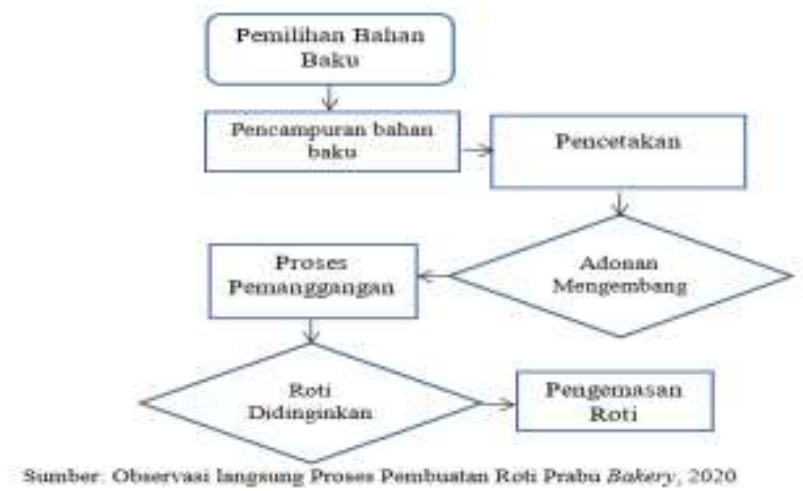

Gambar 2. Statistical Quality Control (dibuat penulis)

Pada gambar menunjukkan bahwa dalam proses awal memerlukan gambaran visual dari urutan suatu proses dalam memproduksi suatu produk. Dengan diagram alir dapat diketahui urutan proses produksi roti dari awal proses hingga akhirnya dikemas dan siap di distribusikan. Selanjutnya diagram sebar yang berfungsi untuk menunjukkan hubungan antara variabel yang satu dengan yang lainnya, dimana kita akan melihat hubungan banyaknya produksi roti dengan jumlah produksi roti yang gagal. Peta Kendali $P$ adalah salah satu jenis Peta Kendali yang menghitung proporsi defective (kegagalan/cacat) pada produksi. Peta Kendali $P$ atau $P$-Chart digunakan apabila jumlah sampel (sample size) yang dikumpulkan tidak tetap.

Adapun langkah-langkah dalam membuat peta kendali sebagai berikut:

a) Menghitung Presentase Kegagalan

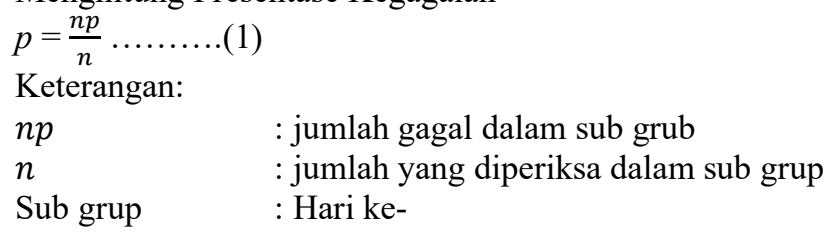

\section{Hasil penelitian}

Prabu Bakery merupakan perusahaan perorangan yang bergerak di bidang pembuatan roti. Perusahaan ini didirikan oleh ibu Rita Susilawati pada tahun 2015 di Kota Palangka Raya, Kelurahan Bukit Tunggal, Kecamatan Jekan Raya. Sistem kerja di Prabu Bakery adalah karyawan masuk dari hari Senin sampai dengan Sabtu. Jam kerja karyawan dimulai dari pukul 04.00 sampai dengan 16.00 WIB. Setiap hari karyawan yang bertugas sebagai membuat adonan dan mencetak roti diharapkan dapat memproduksi roti antara 1.000 sampai 2000 buah roti bahkan lebih.

Dalam meningkatkan sistem dalam produksi pembuatan prabu menggunakan metode proses pemilihan bahan baku dari dalam negeri yang berkualitas dan tersedia tepat waktu. Selanjutnya proses pencampuran bahan baku, proses pencetakan, proses pemanggangan dan proses pengemasan. Melakukan pengendalian proses produksi dan menghasilkan produk yang berkualitas, perusahaan membuat standar 
kualitas produk yang masih dapat diterima untuk menentukan apakah suatu produk dinyatakan baik atau buruk. Dalam kenyataannya yang terjadi di lapangan adalah upaya mencapai dan mempertahankan kualitas produk yang dihasilkannya, perusahaan selalu mendapatkan permasalahan. Permasalahan yang terjadi pada Prabu Bakery adalah roti yang dihasilkan tidak sesuai dengan standar yang telah ditetapkan oleh perusahaan. Faktor-faktor tersebut, antara lain: (1). Tenaga kerja yang kelelahan, kurang fokus dan kurang teliti dalam bekerja dapat mempengaruhi kualitas produk yang dihasilkan. (2). Metode yang digunakan Prabu Bakery yaitu proses pemilihan bahan baku, proses pencampuran bahan baku, proses penggilingan bahan baku, proses pencetakan, proses pemanggangan, proses pengemasan. Jika metode-metode tersebut tidak dilakukan dengan baik, maka hasil produksi roti tidak sesuai dengan standar.

4.1 Hasil Uji Hipotesis

Hasil Perumusan hipotesis yang diusulkan pada penelitian ini yaitu:

a. Diduga pelaksanaan pengendalian kualitas produk pada Prabu Bakery belum dapat meminimumkan produk gagal.

b. Diduga pelaksanaan pengendalian kualitas pada Prabu Bakery berada dalam batas kendali.

c. Diduga faktor-faktor penyebab terjadinya kegagalan produk yang diproduksi oleh Prabu Bakery adalah faktor manusia atau human errors dan faktor metode.

Setelah melakukan analisis peta kendali $P(P$ - Chart) untuk Prabu Bakery yang telah dijelaskan pada hasil penelitian diatas, dapat diketahui yaitu jumlah produk yang diperiksa sebanyak 54.720 buah roti dari hasil produksi Prabu Bakery pada waktu 30 hari. Rata-rata kerusakan produk sebesar 0,0115 atau 1,15\%. Untuk batasan pengawasan atau pengendalian kulitas pada perusahaan yaitu batas kendali atas (UCL) sebesar 0,08 atau $8 \%$ dan batas kendali bawah (LCL) sebesar $-0,06$ atau $-6 \%$ atau bisa dikatakan sama dengan 0 (nol). Untuk mendapatkan hasil maka dibutuhkan diagram sistem sebagai alir Quality Control berikut.

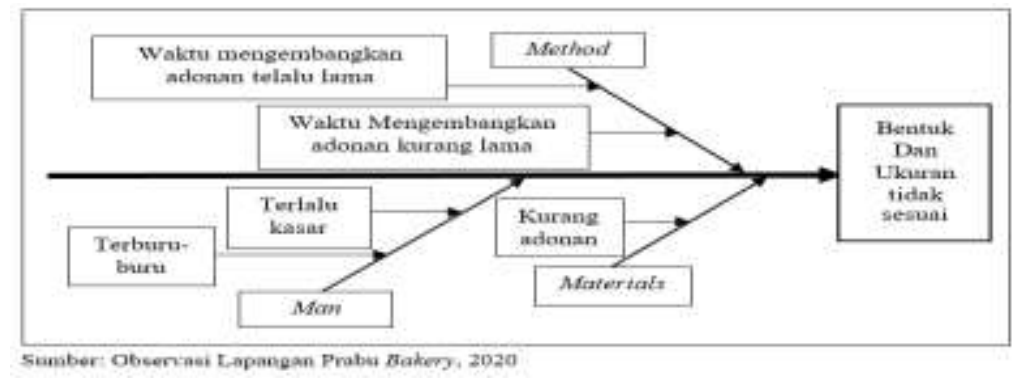

Gambar 3. Diagram Sebab Akibat Jenis Kegagalan Bentuk dan Ukuran Tidak Sesuai

Berdasarkan hasil dari observasi dan dituangkan dalam diagram gambar 3. dapat dikatakan pengendalian kulitas pada Prabu Bakery sudah baik namun masih belum efektif. Terbukti dari hasil analisis rata-rata kerusakan produk yaitu 0,0115 atau $1,15 \%$ yang masih dalam batas kendali yaitu $\leq 10 \%$. Dikatakan belum efektif karena masih terdapat dua titik yang berfluktuasi cukup tinggi mendekati UCL (batas kendali atas) yaitu produksi pada hari ketujuh dan kedelapan. Setelah melakukan analisis sebab akibat, dapat diketahui faktor utama penyebab terjadinya kegagalan dalam produk dikarenakan faktor manusia. Faktor manusia disebabkan oleh kurangnya pelatihan dan pengembangan kemampuan tenaga kerja untuk mengolah roti berkualitas serta kurangnya pengawasan proses produksi dan kepedulian untuk memperbaiki kesalahan produksi dari tenaga kerja itu sendiri terhadap kesalahan yang terus terjadi berulang-ulang, Untuk itu perlu diadakan pelatihan dan pengawasan yang dilakukan pemilik terhadap pekerja demi meningkatkan kualitas produk.

Metode kerja yang banyak menggunakan tenaga manusia dan sistem pengawasan kerja yang kurang rutin dilakukan juga merupakan faktor lain yang dapat menghasilkan kegagalan produk. Bahan baku yang kurang juga merupakan salah satu faktor yang menyebabkan kegagalan produk. Metode Statistical Quality Control (SQC) dalam hal pengendalian kualitas produk dapat meminimumkan produk gagal, karena metode SQC dapat memperlihatkan dan mengontrol seberapa banyak kesalahan yang dapat dimaafkan dalam suatu proses produksi. Hal ini juga menjawab hipotesis dalam penelitian ini yang sudah tercantum diatas. Dengan menggunakan metode SQC juga dapat meminimumkan biaya produksi yang diakibatkan oleh kerusakan produk roti. Dengan menggunakan diagram alir, lembar pengecekan, histogram, diagram sebar, peta kendali $P$, diagram pareto dan diagram sebab akibat dapat dijadikan sebagai alat oleh Prabu Bakery untuk dijadikan bahan pertimbangan dalam pengendalian kualitas produk, mengontrol produksi roti 
menjadi lebih efektif sehingga dapat meminimumkan produk gagal bahkan menuju zero defect pada produk roti Prabu Bakery.

\section{Kesimpulan}

Berdasarkan histogram yang dibuat, dapat dilihat jenis kegagalan yang paling banyak terjadi adalah bentuk dan ukuran tidak sesuai, dengan jumlah kegagalan sebanyak 343 buah roti. Jenis kegagalan yang sering terjadi kedua adalah pengovenan tidak sempurna sebanyak 278 buah roti dan jenis kegagalan yang jarang terjadi adalah adonan tidak sesuai dengan jumlah kegagalan 0 (nol). Sedangkan total kegagalan produk Prabu Bakery selama satu bulan adalah sebanyak 621 buah roti dari total produksi sebanyak 54.720 buah roti. Berdasarkan diagram pareto yang dibuat, dapat dilihat jenis kegagalan yang paling tinggi adalah bentuk dan ukuran tidak sesuai dari roti, dengan persentase kegagalan sebesar 55,23\%. Tingkat kegagalan tertinggi kedua adalah pengovenan tidak sempurna sebesar $44,77 \%$ dan tingkat kegagalan adonan tidak sesuai $0 \%$. Berdasarkan hasil peta kendali, dapat dilihat bahwa kualitas produk masih di dalam batas kendali namun proses produksi masih mengalami penyimpangan. Hal ini dapat dilihat pada grafik peta kendali $P$ yang menunjukkan ada dua titik yang berfluktuasi cukup tinggi. Berdasarkan hasil diagram sebab akibat dapat diketahui faktor-faktor penyebab kegagalan produk, yaitu berasal dari faktor manusia, metode kerja dan bahan baku.

Secara umum faktor yang menyebabkan kegagalan produk adalah faktor manusia. Seperti yang dibahas pada diagram sebab akibat, faktor manusia adalah faktor utama yang menyebabkan kegagalan itu terjadi. Peneliti menyarankan perusahaan perlu melakukan pelatihan, pengembangan dan pengawasan bagi pekerja lama maupun pekerja baru sebelum mereka siap untuk bekerja sesuai dengan standar perusahaan untuk menanggulangi terjadinya kegagalan pada proses produksi guna memajukan perusahaan. Selain itu perlunya perbaikan kualitas tenaga kerja diharapkan dapat mengoptimalkan proses produksi dan mengurangi terjadinya kesalahan yang sama dalam proses produksi yang diakibatkan oleh faktor metode kerja, mesin dan bahan baku, yang dapat diketahui bahwa manusia adalah penggerak dalam kegiatan proses produksi yang terjadi dalam perusahaan.

\section{REFERENSI}

[1] Bakhtiar, S., Tahir, S., \& Hasni, R. A. (2013). Analisa pengendalian kualitas dengan menggunakan metode statistical quality control (SQC). Industrial Engineering Journal, 2(1).

[2] Ilham, M. N., Brasit, N., \& Dewi, R. S. (2012). Analisis Pengendalian Kualitas Produk dengan Menggunakan Statistical Processing Control (SPC) pada PT Bosowa Media Grafika (Tribun Timur). Skripsi. Universitas Hasanudin. Makasar.

[3] Aden, A., \& Setiawan, T. H. (2019). Analisis Pengendalian Kualitas Produk Roti Melalui Kartu Kendali Proporsi (Studi Kasus: CV. Spesial Bakery). Statmat: Jurnal Statistika Dan Matematika, $1(1), 25-43$

[4] Hairiyah, N., Amalia, R. R., \& Luliyanti, E. (2019). Analisis statistical quality control (SQC) pada Produksi roti di Aremania Bakery. Industria: Jurnal Teknologi dan Manajemen Agroindustri, 8(1), 41-48.

[5] Faisal, M., \& Aulawi, H. (2016). Analisis pengendalian kualitas roti di home industri mahabah garut. Jurnal Kalibrasi, 14(1).

[6] Silalahi, F. A., Wahyuda, W., \& Saptaningtyas, W. W. E. (2020). Analisis Pengendalian Kualitas Produk Roti Gepeng Menggunakan Metode Six Sigma: Studi Kasus Roti Gepeng ZB Samarinda.

[7] Yana, S. (2015). Analisis Pengendalian Mutu Produk Roti pada Nusa Indah Bakery Kabupaten Aceh Besar. Industrial Engineering Journal, 4(1).

[8] Hariyanto, M. A., Fauji, D. A. S., \& Riani, L. P. (2017, December). Pengendalian Kualitas Produk Roti Tawar "Della". In Seminar Nasional Manajemen, Ekonomi, Akuntansi (Vol. 2, No. 1, pp. $15-$ 22).

[9] Heruhidayat, A. (1998). Analisis faktor-faktor yang mempengaruhi penerapan manajemen mutu terpadu pada Galih Bakery, Ciledug, Tangerang, Banten.

[10] Fibriany, F. W. (2018). Penerapan Manajemen Mutu Terpadu Untuk Menurunkan Reject Produksi Roti Bun di PT. SFP. Cakrawala-Jurnal Humaniora, 18(1), 31-36.

[11] Toendan, R. Y. (2019). Manajemen Pengetahuan Sebagai Keunggulan Kinerja Dalam Strategi Berbasis Pengetahuan. Jurnal Riset Akuntansi (JUARA), 9(2), 31-38. 
IEMBA: Jurnal Ekonomi Pembangunan, Manajemen dan Bisnis, Akuntansi

Volume 1. No. 1 (Maret 2021) / e-journal.upr.ac.id

[12] Sambung, R. (2020). Pelatihan dan Kepemimpinan Visioner dalam meningkatkan Kreativitas Pegawai di Kalimantan Tengah. Matrik: Jurnal Manajemen, Strategi Bisnis dan Kewirausahaan, 169-181.

[13] Elmas, M. S. H. (2017). Pengendalian kualitas dengan menggunakan metode statistical quality control (SQC) untuk meminimumkan produk gagal pada toko roti barokah bakery. WIGA-Jurnal Penelitian Ilmu Ekonomi, 7(1), 15-22.

[14] Meitiana, M. (2017). Perilaku Pembelian Konsumen: Sebuah Tinjauan Literatur Theory of Planned Behavior. Jurnal Ekonomi Modernisasi, 13(1), 16-24.

[15] Hukom, A. (2014). Hubungan ketenagakerjaan dan perubahan struktur ekonomi terhadap kesejahteraan masyarakat. Jurnal Ekonomi Kuantitatif Terapan.

[16] Muzakir, M. (2018). Analisis Pengendalian Kualitas (Quality Contol) Produk Roti Menggunakan Alat Bantu Statistik. Jurnal Optimalisasi, 1(1).

[17] Norawati, S., \& Zulher, Z. (2019). Analisis Pengendalian Mutu Produk Roti Manis Dengan Metode Statistical Process Control (Spc) Pada Kampar Bakery Bangkinang. Jurnal Menara Ekonomi: Penelitian dan Kajian Ilmiah Bidang Ekonomi, 5(2). 